\title{
School social work: A school-based field placement
}

\section{Doris Testa}

Dr Doris Testa, dually qualified in social work and education, is a staff member of Victoria University, Melbourne. Her work is mainly in the areas of field education and school-based social work. While a school principal, Dr Testa introduced social work students and social work programmes to the formal student wellbeing programmes. Dr Testa was a recipient of the 2003: Madeline Crump Award - 'Outstanding Fieldwork Teaching in Social Work'. Doris Testa can be contacted at Doris. Testa@vu.edu.au.

\begin{abstract}
This article addresses the placement of social work students in a non-traditional social work setting: the Victorian Catholic primary school. Considering the different elements of field education placements, this article discusses how a field education placement was purposefully structured to guide the social work student through the process of integrating theory and practice. Drawing on qualitative and quantitative data, the article describes the structure of the placement and how respondents viewed the success or otherwise of the orientation activities, opportunities to integrate theory with practice, the development of practice skills, supervision and the development of school/ university partnerships. The data indicated that a purposefully structured placement which provides students with a variety of learning opportunities and which is supported by clearly focused supervision are key contributors to the success of school-based field education placements.
\end{abstract}

\section{Introduction}

The Australian Association of Social Work (AASW), the registering body for Australian social workers, is clear about the centrality of field education. Instructing universities to give the field placement 'full academic' status, the AASW stipulates that students must undertake 780 hours of field placement in two different social work settings over two academic years (AASW, 2008). The underlying principle to this requirement is that field education provides the opportunity for students to test theory, practice and values (Beddoe \& Maidment, 2009; Egan \& Testa, 2010). Authors have described the field experience as potentially either validating the student's choice to pursue a social work career or becoming the catalyst for the student's decision to abandon the career choice altogether (Beddoe \& Maidment, 2009).

However, while the field experience is a mandatory component of social work education, the task of securing settings in which students can undertake the placement is becoming increasingly difficult. Scholars attribute this firstly to universities offering postgraduate entry qualifications alongside the traditional undergraduate programmes and secondly to the community and human sector's reluctance to provide placements. The first development has led to an increase in the numbers of placements universities need to secure. 
The second development is a consequence of social workers' 'weak public' image; 'low professional visibility'; an unwillingness within the public sector to mentor and foster social work students; the lack of experienced social workers who are eligible and willing to supervise social work students; and the tendency for workplaces to want capable students to whom they can allocate a workload, thus offsetting some of the workplace pressures (Barton, Bell, \& Bowles, 2005; Hay, O'Donoghue, \& Blagdon, 2006). The Victorian Catholic school is one site that can provide field education opportunities, build the professional profile of social work and offset some of the workplace pressures placed on student wellbeing staff.

\section{Victorian Catholic schools and student wellbeing}

In 2006, a comprehensive restructuring of the Catholic Education Office, Melbourne services and operations, 'One Body, Many Parts - Student Wellbeing Strategy 2006-2010' (2006b), rebadged its Pastoral Care Unit as the 'Student Wellbeing Unit' and restructured how the unit was to oversee and service student wellbeing approaches in Victorian Catholic schools. This unit manages critical incidents, helps negotiate student wellbeing services with and on behalf of schools and provides consultation services, steers and promotes the development of student wellbeing in Victorian Catholic schools towards health actions and health promotion self-management (Catholic Education Office Melbourne, 2006b). The unit does this by providing professional development activities to key leaders in schools and by concentrating their professional development on skills and knowledge that promote student resilience, primary prevention (programmes that build resilience, facilitate belonging and promote wellbeing) and early intervention (programmes that target students identified as 'at risk') programmes and brokering services across sectoral and disciplinary divides (Catholic Education Office Melbourne, 2006b).

A key plank of the Catholic Education Office, Melbourne's student wellbeing policy approach is the appointment of Student Wellbeing Coordinators who have completed postgraduate studies in student wellbeing. In 2009 the student wellbeing coordinator's role was filled by the Principal, Deputy Principal, Year level coordinators, student wellbeing coordinators or Faculty coordinators (Catholic Education Office Melbourne, 2006a). Time allocation for the student wellbeing role can range from a minimum of four hours per week to full time.

Cahill, Shaw, Wyn and Smith (2004) have undertaken preliminary research into how student wellbeing coordinators in Catholic schools are managing the role. They state that student wellbeing coordinators undertaking the coordination of student wellbeing tasks on top of their teaching role were time poor and that their training was highly individualised. They also found that teachers were unable to influence local structures and organisations and that scant attention was being given to the social, economic or political causes of student underachievement. This research raised points of interest:

a) how able are student wellbeing coordinators to fulfil their role as health promotion educators and facilitators when the structures that define their role restrict the time available to them, do not recognise gaps in their knowledge and skills and leave them at a distance from the school-based mechanisms that can influence the decision-making processes and 
b) how can the visibility of social work be promoted in Catholic schools and the Catholic Education Office, Melbourne, as a legitimate partner who can deliver and develop whole school student wellbeing approaches alongside student wellbeing coordinators?

This research, a case study of the contribution of field education to the student wellbeing programmes within one Victorian Catholic school, suggests that field education is one way of making social work visible in the school setting and introducing expert skills and knowledge to student wellbeing programmes while simultaneously assisting student wellbeing coordinators to fulfil their complex roles and fulfilling the Catholic Education Office, Melbourne's student wellbeing strategy.

The case research is the St. Paul's Model ('the Model'), a school-based student wellbeing model which began to take shape in 1994, and preceded the Catholic Education Office, Melbourne's student wellbeing strategy and the availability of the student wellbeing coordinator position in Victorian Catholic schools. The research reported in this article is one Catholic school's attempt to address student wellbeing by embedding social work field education programmes in the formal and professional health actions undertaken within the school site.

\section{A case study: The St. Paul's Model}

Located within a low socio-economic but culturally rich area west of Melbourne, Australia, St. Paul's school is situated in the second most disadvantaged municipality in Melbourne and within the third most disadvantaged local government area (Brimbank City Council, 2009). The population of St. Paul's school is characterised by high unemployment, lowlevel household incomes, high proportions of newly arrived migrants / refugees and a high proportion of non-English-speaking parents/carers. Responding to this socio-economic profile, over a period of 12 years from 1994-2005, staff at this school, led by its principal, attempted to integrate programmes that addressed both wellbeing and learning into the School's formal and professional student wellbeing arrangements.

Situated within the socio-ecological health and the student wellbeing discourses, both of which recognise the interwoven relationship that exists between the individual and their environment and the social, emotional, economic and cultural impact of student wellbeing and student achievement, the Model was designed to provide a comprehensive, well coordinated response to the needs of students and the whole school community. The Model's components included interventions along a continuum of care: early intervention, prevention, intervention and post-intervention (i.e.) restoring wellbeing (DEET, 1998).

Social work students undertaking their first or second 70-day field education placement contributed to the Model. These students were drawn from six Victorian schools of social work: Victoria, LaTrobe, Monash, Melbourne, Deakin and RMIT universities. Working alongside the principal, an AASW accredited social worker, they developed and implemented programmes that addressed social, economic and educational disadvantage (AASW, 2006). What began in 1994 as one programme with two social work students from Victoria University, as a student at-risk programme, evolved by 2005 into a social work student unit, responsible for facilitating 12 student wellbeing programmes. Seventy-nine social work students participated in the Model's implementation between 1994 and 2005. 
As indicated in Table one below, as social work students became more accessible to student wellbeing programmes, opportunities to add social work student-led wellbeing programmes became possible. These programmes included individual casework with at-risk students, community development and advocacy programmes, policy and research.

Table one. Model components by student wellbeing focus and year introduced.

\section{Programme start Emphasis}

Lunch programmes

Classroom (Social Skills) programmes

Breakfast Club

Participation in School Camp programme

Research: 'Vietnamese Participation

in St Paul's School'

Submission Writing

SEASONS - programme for children who have

experienced grief and loss 1997

Research: 'Bullying Audits'

Transition programme

Swimming programme

Welfare committee referrals

Research: 'Parent/Carer Experiences of

the Enrolment Processes'

Special programmes and School Focused

Youth Service representation

Playground programme

Homework Club programme

After School Hours Care programme

and policy development

Community building - Artist in Residence

programme and Jubilee celebrations

Research: Breakfast Club Report

Research: 'Bullying Audit'
1999

2000

2000

2001

1994

1994

1994

1995

1996

996

2001

2002

2003

2004

2004

2005

2005

2005
Primary prevention/Early intervention Intervention

Primary prevention/Early intervention Early Intervention

Primary prevention

Primary prevention/Early intervention

Postvention (Restoring wellbeing)

Primary prevention/Early intervention/ Intervention

Primary prevention

Primary prevention Intervention

Primary prevention/Early intervention

Primary prevention/Early intervention/ Intervention

Intervention

Intervention

Intervention

Primary prevention

Primary prevention/Early intervention

Primary prevention/Early intervention

The following section describes how the Model was structured and how the social work field education placement developed to integrate health and wellbeing policies and practices.

\section{Social work field education and its contribution to the Model}

The challenge for schools that accept students for a field education placement is to provide a learning experience that is supportive and educative, that fulfils the requirements of a social work placement and that introduces the student to the student wellbeing and student achievement discourses that underpin social work practice in schools (Beddoe \& Maidment, 2009; Cleak \& Wilson, 2007). This challenge was integral to the Model's structure.

The social work field education placement emphasised the three characteristics of professionalism: theory, practice and research (Humphries, 2005) and was purposefully structured 
to guide the social work student through the process of integrating theory and practice. The placement began with a two-week period of orientation to the school's staff, programmes, policies and practices. All of the orientation activities focused students on the goals, values and ethics shared by teachers and social workers, the interdependence of student wellbeing and student achievement and classroom observations and meetings with staff members. During these activities, students began noting areas of learning that could be included in the learning agreement. In week three students developed their learning goals in relation to the learning opportunities available within the school, the interests and abilities of the students and the teaching and learning style of both the supervisor and social work student (Cleake \& Wilson, 2007). Accommodating for learning styles was achieved by completing a Learning Style Questionnaire, discussing and then integrating the questionnaire results into the learning agreement (Cleake \& Wilson, 2007). During this phase, students had daily contact with the supervisor. Together the student and supervisor discussed the significant points of overlap and difference between teaching and social work skills and knowledge, and the socio-ecological and student wellbeing discourses.

Following the orientation phase of the placement, social work students, in collaboration with the social work supervisor, were allocated responsibility for particular programme areas. Social work students then wrote their individual Learning Agreements. Weekly individual and/or group supervision, central to the learning experience, provided a forum for the learning review to ensure that social work students had the educative, supportive and administrative functions of supervision (Beddoe \& Maidment, 2009; Kadushin \& Harkness, 2002).

During the course of their placement, social work students used reflective journals, case notes, group presentations to the teaching staff, peer presentations and daily updated efolios as the main teaching and learning tools. Between formal supervision sessions, social work students were required to keep an e-portfolio containing critical reflections, case notes and programme, project and policy development notes. The supervisor had daily access to these online files and gave daily feedback, suggesting future actions or readings and noting topics for supervision. Additionally, social work students were clear that they could have supervision on 'as needed' bases, formal and/or informal.

So, how successful was this placement for social work students and is the school site an unexplored and valuable learning opportunity for the training of social workers? The next section outlines the research aims and methodology.

\section{Research aim}

The research goal was to see whether the school-based placement met university and AASW requirements and whether such a placement assisted social work students to develop and integrate their theoretical and practice skills.

\section{Methodology}

The methodology used a descriptive, explanatory case study methodology and the research method used data gathering, which combined a qualitative survey and quantitative data (Yin, 2009). Qualitative data, taken from focus group transcripts or open-ended questions 
included in the surveys, was used to understand, describe and map the social work student's experience within a specific context; quantitative data was used to supplement and validate the qualitative data (Yin, 2009).

While many participants may have been identified as relevant to the research, for example, all St Paul's students, all parents and carers, all staff, social work students from every partner university or all field educators, pragmatically the participant group needed to be contained and manageable. Consequently, the participants were bounded by place, i.e. students and Field Education Co-ordinators from Victoria University; time, i.e. 1994 to 2005; and experience, i.e. participants who had been involved in or who had knowledge of the St Paul's Model from 1994 to 2005 (Bronson, 1995; Corbin \& Strauss, 1990). Using these criteria, 20 teachers, 20 primary school aged students, 10 Parent Partnership Team members, 18 social work students and four Field Education Coordinators chose to participate in the research. This article uses the survey data returned by social work students and Field Education Coordinators and qualitative data returned by social work students, Field Education Coordinators and teachers.

\section{Data gathering and analysis}

Twenty social work students and four Field Education Coordinators were sent information packs inviting completion and return of the consent form and survey. Eighteen (75\%) Victoria University social work students, 13 students undertaking their first social work placement and seven students undertaking their final social work placement, agreed to participate in the research. Participant responses were identified by way of an acronym and number e.g. SWS1 = social work student 1, FEC1 = Field Education Coordinator.

Four (100\%) Field Education Coordinators agreed to participate in the case study. The data used in this article incorporates the survey responses that were concerned with the social work students' learning experiences. Mirror questions were asked of the social work students and Field Education Coordinators. The survey had four sections:

1. Section one requested information about the participant and the participant's involvement in 'the Model'.

2. Section two consisted of a one-dimensional scaling component asking participants to use a Likert Scale, which invited the research participants to select one of five categories to indicate her / his experience of each of the learning domains: Orientation activities, Theory and Conceptual skills, Practice skills and Supervision. The five categories were 'Strongly Disagree', 'Disagree', 'Unsure', 'Agree' and 'Strongly Agree'.

3. Section three gave participants the opportunity to contribute their personal views on factors that they felt enabled/ empowered or hindered/ constrained their learning experiences (Neuman, 2006).

4. Section four invited the participants to offer their thoughts on programme additions and/or changes that would make or advance the effectiveness of 'the Model' and/or the field education experience.

Survey results were added to focus group documentation that was collected during the research phase (Yin, 2009). Raw qualitative data was converted using SPSSX, arranged into themes, coded and analysed (Sarantakos, 2005). 
The next sections discuss the research findings concerning Orientation activities, Theory and Conceptual skills, Practice skills and Supervision.

\section{Findings}

\section{Orientation activities}

Analysis of the data indicated that both social work students and Field Education Coordinators found the Orientation activities were useful in providing a context for practice. Both social work students and Field Education Coordinators indicated a high-frequency satisfaction with the Orientation activities. Eleven social work students $(61.11 \%)$ and three Field Education Coordinators (75\%) 'strongly agreed' and seven social work students $(38.89 \%)$ and one Field Education Coordinator (25\%) 'agreed' that the Orientation activities helped students to understand the school and the place of social work within the school site.

\section{Theory and Conceptual skills}

The second question in the survey asked social work students and Field Education Coordinators to indicate how well the placement provided opportunity for students to integrate theory with practice. Ten social work students $(55.56 \%)$ and two Field Education Coordinators (50\%) 'strongly agreed' and eight social work students $(44.44 \%)$ and two Field Education Coordinators (50\%) 'agreed' that the placement gave opportunity for the integration of theory and practice. All the social work students and the Field Education Coordinators 'strongly agreed' that the placement was relevant to social work studies.

Additionally 11 students (61.11\%) ‘strongly agreed' and seven students (38.89\%) ‘agreed' that the placement helped them to reflect on the impact of policies, economics and structures of schooling. Both social work students and Field Education Coordinators 'strongly agreed' or 'agreed' that the placement offered students opportunity to apply a critical lens to the reasons behind the specific programmes offered in the Model e.g. Breakfast Club, Lunch Programme and Homework Club. Students also reported that the placement developed critical thinking, analytical skills and gave them an increased understanding of the critical discourse and social inequality.

Comments from the social work students indicated that the field education placement helped them practise their theoretical skills and knowledge:

My knowledge of childhood development was really stretched [SWS].

I had to know what to look for when I was assessing kids in the Transition Programme [SWS10]. It's been quite different for me (at St. Paul's). This (placement) brings together community life, whether it be family, organisational or personal, we are bringing the community together [SWS 12].

Field Education Coordinators also recognised the socio-economic and cultural disadvantage experienced by the St. Paul's students and families and the role that social work, particularly community development skills, played in dampening further disadvantage:

Combining work with individuals with community development-type work, the social work students, brought resources into the school without stigmatising the community [FEC1]. [Social work involvement] meant that people could be helped without blaming them for their circumstances [FEC4]. 
Both Field Education Coordinators and social work students indicated that the learning opportunities offered during the placement were challenging but manageable with all Field Education Co ordinators $(100 \%)$ and 12 social work students $(66.67 \%)$ 'strongly agreeing' and six $(33.33 \%)$ 'agreeing that the tasks were challenging but manageable.

That the social work students were able to link the theories that were presented in their university course had a positive impact on their Practice skills.

\section{Practice skills}

Data indicated evidence that the field education placement met the expectation that social work students develop, refine and effectively demonstrate a range of interpersonal, advocacy, negotiation, and conflict resolution and communication skills (AASW, 2006). Social work students 'agreed' (39\%) or 'strongly agreed' (61\%) and Field Education Coordinators 'strongly agreed' (50\%) or 'agreed' (50\%) that the placement met AASW requirements.

Social work students commented on the opportunity that the field education placement provided for the development of their assessment and intervention skills:

Assessments are about the social as well as the academic readiness of kids to start school (SWS K). I am certain that [D] will need referral to the social skills programme when he starts, he finds it hard to settle, he found it hard to settle and follow direction (SWS R).

Qualitative data from the teachers indicated that they recognised the expert community development, networking skills and knowledge that social work students brought to the school site:

They[the social work students] point people in the right direction - get access to different programmes that they may get access to - programmes that teachers aren't aware of because they're not social workers [Teacher A].

Teachers also identified the social work students' ability to develop and apply casework, interpersonal, advocacy, negotiation, and conflict resolution and communication skills to their allocated tasks and responsibilities:

...I try to think of them as not working with the kids academically, I want them to help the child socially [Teacher M3].

You know there are other advantages, not just if kids are in trouble, the social work students might see that a kid be doing something great that the teacher missed and be able to encourage them and give them a pat on the back [Teacher N].

Field Education Coordinators named as a challenge the way that casework is represented within the social work course and the way it is delivered at a school site. As one wrote:

There appears to be a view that there is no 'casework' offered within the project and students grapple with the notion that the relationship with school students takes a different form to the traditional 1:1 relationship. This introduces a challenge for the way casework is taught, for understanding of casework and for understanding the role of social work in the school setting [FE2].

Central to the social work students' learning was supervision. 


\section{Supervision}

The specific theoretical frameworks used while on field education placement were revisited during supervision. All respondents 'strongly agreed' or 'agreed' that supervision met the required AASW standards. Four (100\%) Field Education Coordinators and $11(61 \%)$ of the social work students 'strongly agreed' and seven (32\%) 'agreed' that supervision was focused on the integration of theory and practice, afforded an opportunity to integrate theory and practice, and provided a balance of structure and guidance. All Field Education Coordinators and nine (50\%) of the social work students 'strongly agreed' and nine (50\%) 'agreed' that supervision focused on the empowerment of the students.

Regarding individual supervision, two (50\%) Field Education Coordinators and 11 $(61.11 \%)$ social work students 'strongly agreed' and two (50\%) Field Education Coordinators and seven $(38.89 \%)$ social work students 'agreed' that individual supervision met student needs. In contrast to Field Education Coordinators, social work students indicated a greater preference for group supervision. Three (75\%) Field Education Coordinators and 14 (77.78\%) social work students 'strongly agreed' and one Field Education Coordinator (25\%) and four $(22.22 \%)$ social work students 'agreed' and that group supervision met students' individual needs.

The mixture of individual and group supervision was named as a formative learning experience and as an opportunity to learn from other students and test the theoretical theories that each brought to field education:

It was a great experience having students from other universities. It was interesting to compare and contrast the different theories and styles of practice. I felt we brought something to the table and we all were able to learn from each other [SWS12].

Additionally, the supervisor's encouragement and skill was mentioned as a contributing factor in the positive function of supervision:

Having both individual and group supervision and an experienced supervisor [SWS 3].

Overall I had a wonderful experience ... other students and very skilled and encouraging

[supervisor] inspired me about social work in schools [SWS 20].

Finally, the survey asked social work students and Field Education Coordinators to express an opinion about the importance of the placement as a way of engaging with universities. All (100\%) Field Education Coordinators 'strongly agreed' that the Model formed the basis of a positive and productive relationship with the university and that the partnership was beneficial to both partners. Additionally, $18(100 \%)$ social work students responded that they would recommend the school-based placement to other students and that the school-based placement is beneficial to all stakeholders: school, students and university.

The data presented in this article provides valuable information for school-based field education placements.

\section{Discussion}

This article set out to report on research that mapped the success or otherwise of the field education placement within a particular setting and within a particular programme. The 
measure of the success or otherwise of the field education placement was based on the AASW's (2008) requirement that field education must provide the opportunity for social work students to test theory, practice and values. Data, including qualitative and quantitative data, was collected about Orientation activities, Theory and Conceptual skills, Practices Skills and Supervision.

Data suggests that key to a successful school-based social work field education placement is:

- A well-structured field education programme that assists students to understand the contribution of social work to schools and the values shared by teachers and social workers

- A learning environment that allows social work students to participate in a range of student wellbeing programmes

- The supervisor's commitment to individual and group supervision of the social work students

- Individual and group supervision that focuses on making explicit the theoretical underpinnings of school-based social work

- An explicit focus on community development and anti-oppressive theories

- Multiple social work students on placement simultaneously and drawn from different schools of social work, which promotes rich dialogue and reflection amongst the social work students.

While recognising that the positive outcomes for the social work students were driven by the structure of the placement, the research also suggests that what works for social work students also contributes to the advancement of student wellbeing programmes within schools. Social work field education undertaken in school settings can benefit the development of student wellbeing approaches as well as the stakeholders in the school site: primary-aged students, their families, teachers, social work students and universities. Benefits include:

- An expansion of the student wellbeing programmes offered within the school site

- The contribution of social work skills and knowledge to school-based student wellbeing programmes

- Strengthened community engagement that builds school/home partnerships.

Importantly, the Model provided school-based social workers a way in which to use social work's expert skills and knowledge to promote social functioning, and ameliorate environmental conditions that impede the learning process. Additionally, and importantly, the Model can be an exemplar to both the Catholic Education Office, Melbourne, and schools of social work of how school-based field education programmes can contribute to student wellbeing programmes and effectively prepare emerging social workers to work in a specialised field of practice.

\section{Recommendations for future research}

The findings, although significant for understanding the St Paul's Model, have some limitations. One of these limitations was that the research focused on one Victorian Catholic primary school. Future research could map the transferability of the Model to another 
school to see if the social work contribution, adjusted to incorporate the research findings, was successful.

A second limitation was that the Model relied on the principal's leadership and her social work knowledge and skill. Future research could pursue the effectiveness of the Model when transferred to another Victorian Catholic primary school, with an onsite or an offsite social worker who was part of a student wellbeing core team and worked with or without social work students. Such research would return data on the importance of having a qualified social worker rather than a qualified teacher to implement student wellbeing programmes and the influence of the positional power of the principal on the development of the model. This research would also return evidence of how universities could continue to engage schools in the training of social workers.

\section{Conclusion}

A school-based field education placement can play an important part in the development of social work skill and expertise. A well thought out field education programme that is integrated into the formal and professional student wellbeing structures of the school can benefit both the emerging social work professional and the needs of the school community. Social work students can be helped to integrate theory with practice if purposeful, explicit and well-structured learning opportunities are provided for the students. Critical to this learning experience is a constructive supervisory experience, one that enables social work students to manage and articulate their learning.

The benefit to the school of such a placement is the positive contribution that such expert skills and knowledge and engagement with universities bring to the formal and professional student wellbeing arrangements within a school while the social work profession gains greater visibility in a non-traditional social work setting.

\section{References}

AASW. (2006). Practice standards for social workers in schools. Melbourne: AASW.

AASW. (2008). Australian social work education accreditation standards. Canberra: Australian Association of Social Workers.

Barton, H., Bell, K., \& Bowles, W. (2005). Help or hindrance? Outcomes of social work student placements. Australian Social Work, 58(3), 301-312.

Beddoe, L., \& Maidment, J. (2009). Mapping knowledge for social work practice, critical intersections (1st ed.). South Melbourne: Cengage Learning.

Brimbank City Council. (2009). Demographics. Retrieved 22/01, 2009, from http:/ / www.brimbank.vic.gov.au/.

Bronson, D. E. (1995). Introduction to research: Strategies for health and human services/the use of research in social work practice: A case example from school social work (Book). Social Work, 40(5), 710-711.

Cahill, H., Shaw, G., Wyn, J., \& Smith, G. (2004). Translating caring into action: An evaluation of the Victorian Catholic Education Student Welfare Professional Development Initiative. Melbourne: Australian Youth Research Centre.

Catholic Education Office Melbourne. (2006a). CEOM Annual Report 2006. Retrieved 27 / 09/2007, from http: / / web. ceo.melb.catholic.edu.au/uploads/publications/annual_report/2006/section3.

Catholic Education Office Melbourne. (2006b). One body, manyy parts. Retrieved 15th May, 2007, from http:/ / ceo. melb.catholic.edu.au/.

Cleak, H., \& Wilson, J. (2007). Making the most of field placement (2nd ed.). South Melbourne: Thomson.

Corbin, J., \& Strauss, A. (1990). Grounded theory research: Procedures, canons, and evaluative criteria. Qualitative Sociology, 13(1), 3.

DEET. (1998). Framework for student support services in Victorian Government schools: Professional development group.

Egan, R., \& Testa, D. (2010). Models of supervision. In K. Stagnitti, A. Schoo \& D. Welch (Eds.). Clinical and fieldwork placement in the health professions (1st ed.), pp. 145-158. South Melbourne: Oxford. 
Hay, K., O’Donoghue, K., \& Blagdon, J. (2006). Exploring the aims of social work field education in the registration environment. Social Work Review, Summer, 20-28.

Humphries, B. (2005). From margin to centre: Shifting the emphasis of social work research. In D. Adams, L. Dominelli \& M. Payne (Eds.). Social work futures: Crossing boundaries, transforming practice (pp. 279-292). United Kingdom: Pan Macmillan.

Kadushin, A., \& Harkness, D. (2002). Supervision in social work (4th ed.). New York: Columbia University Press.

Neuman, L. (2006). Social research methods: Qualitative and quantitative approaches (6th ed.). U.S.A.: Pearson International.

Sarantakos, S. (2005). Social research (3rd ed.). China: Palgrave Macmillan.

Yin, R. (2009). Case study research: Design and methods (4th ed., Vol. 5). Thousand Oaks CA: Sage. 